\title{
Disease-associated anti-bovine serum albumin antibodies in Type 1 (insulin-dependent) diabetes mellitus are detected by particle concentration fluoroimmunoassay, and not by enzyme linked immunoassay
}

\author{
J. Karjalainen ${ }^{1,4}$, T. Saukkonen ${ }^{3}$, E.Savilahti ${ }^{2}$ and H.-M.Dosch ${ }^{1}$ \\ ${ }^{1}$ Department of Immunology and Cancer, The Hospital for Sick Children, Toronto, Ontario, Canada, ${ }^{2}$ First and ${ }^{3}$ Second Department \\ of Paediatrics, University of Helsinki, Helsinki, ${ }^{4}$ Department of Medical Microbiology and Paediatrics, University of Oulu, Oulu, Finland
}

\begin{abstract}
Summary. We recently developed a particle concentration fluoroimmunoassay for the measurement of serum antibodies to bovine serum albumin in patients with Type 1 (insulin-dependent) diabetes mellitus. We observed elevated IgG-anti-bovine serum albumin antibodies in $100 \%$ of newly-diagnosed diabetic children and in $2.5 \%$ of matched control children. Here we compare the fluoroimmunoassay and the more commonly available enzyme linked immunoassay technique, exchanging coded serum samples from 40 newly-diagnosed diabetic children and 179 control children between two laboratories. Particle concentration fluoroimmunoassay detected elevated IgG-anti-bovine serum albumin antibodies in all diabetic children, enzyme immunoassay in $25 \%(p<0.0001)$. Fluoroimmunoassay detected elevated levels in $2.2 \%$ and enzyme immunoassay in $10 \%$ of control children $(p<0.002)$. Elevated IgA-antibovine serum albumin antibodies in patients were slightly more often detected by fluoroimmunoassay than by enzyme immunoassay, while in control children enzyme immunoassays detected elevated levels three times more often $(p<0.01)$. Values measured in either assay showed overall no
\end{abstract}

correlation in either patient $\left(\operatorname{IgG}: r_{\mathrm{s}}=0.28 ; \operatorname{IgA}: r_{\mathrm{s}}=0.11\right)$ or control sera (IgG: $r_{\mathrm{s}}=0.02$; IgA: $\left.r_{\mathrm{s}}=-0.05\right)$. Fluoroimmunoassay for IgG was 100\% disease-sensitive (enzyme immunoassay: $25 \%, p<0.0001)$ and more disease-specific (IgG; $p<0.02$ ). Our findings demonstrate that these assay techniques detected distinct subsets of anti-bovine serum albumin antibodies with little (IgG) or some (IgA) overlap. In fluoroimmunoassay procedures, antigen:antibody binding occurs within 1-2 min while hours are allowed in an enzyme immunoassay. Antibodies with high on-off binding rates typical for immune responses following hyperimmunization are therefore measured preferentially by particle concentration fluoroimmunoassay and it is these antibodies which appear to be associated with diabetes. These observations emphasize the need for epidemiological surveys to validate immunoassay procedures used for clinical purposes.

Key words: Bovine serum albumin antibodies, Type 1 (insulin-dependent) diabetes mellitus, enzyme linked immunoassay, particle concentration fluoroimmunoassay.
Based on observations in diabetes-prone BB-rats, we recently identified a small peptide ("ABBOS-peptide") in bovine serum albumin (BSA, pos.153-168, GenBank access number: A03232) as a candidate trigger of Type 1 (insulin-dependent) diabetes mellitus [1]. BSA and in particular the ABBOS peptide share an immunologically cross-reactive epitope with $\mathrm{p} 69$, a $\gamma$-interferon inducible islet Beta-cell surface protein detected by anti-BSA and anti-ABBOS antibodies which occur in all Type 1 diabetic patients or in animals immunized with BSA or ABBOS [2, 3]. Neonatal tolerization with BSA and removal of dietary whey protein prevents diabetes in BB rats and NOD mice $[1,3-5]$. We proposed that dietary BSA/ABBOS initiates an immune response in genetically susceptible hosts (DR3, DR4, DR3-DR4, DQ $\beta$ non-Asp ${ }^{57}$ ) that culminates in the destruction of insulin producing Beta cells [6].
To evaluate the relevance of this hypothesis in man, we developed a particle concentration fluoroimmunoassay technique (PCFIA) [7-11] for the measurement of serum BSA antibodies the bulk of which were found to be ABBOS-specific by solid phase epitope mapping [6]. We found that $100 \%$ of 142 newly-diagnosed diabetic children had significantly elevated IgG-anti-BSA antibodies (61\% for the IgA isotype) compared to below $3 \%$ of matched control children and adult control subjects [6].

Active BSA-specific serology is typical for diabetic NOD-mice and BB-rats $[3,12,13]$, and was preferentially observed in a proportion of children and adults with Type 1 diabetes $[14,15]$. In addition, antibodies to cow's milk proteins have been associated with Type 1 diabetes $[16,17]$. These studies employed enzyme immunoassay (EIA) techniques and differences between diabetic sub- 
A

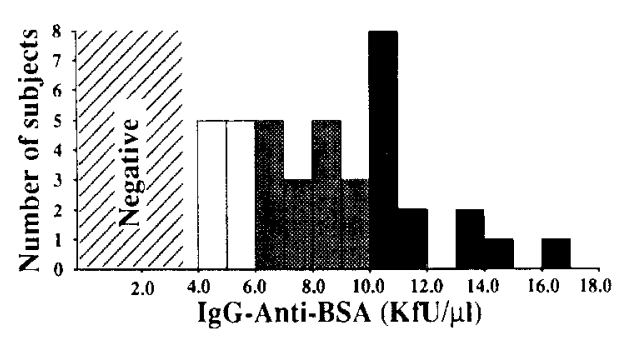

C
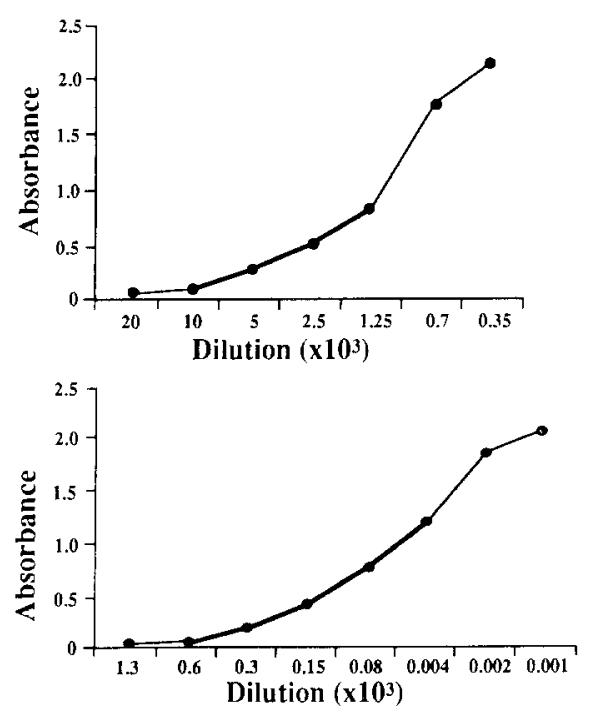

B
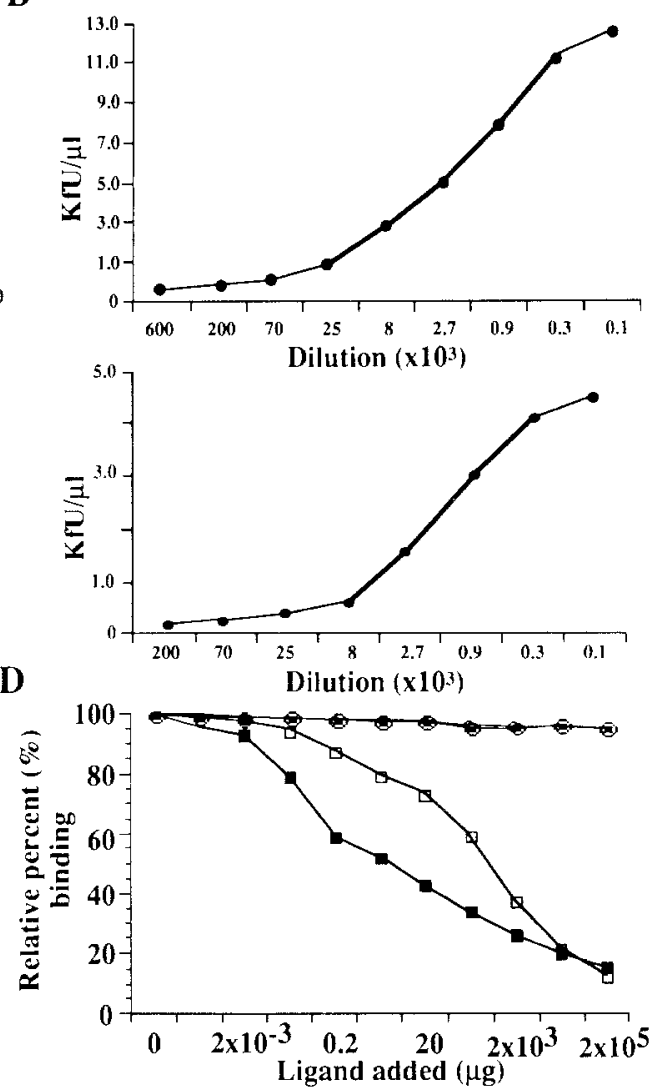

Fig. 1. A Distribution of moderately- (white bars) and highly elevated (black bars) IgG-antibovine serum albumin (BSA) antibodies in 40 diabetic children as determined by particle concentration fluoroimmunoassay (PCFIA). B: PCFIA standard curve for a serum pool (from diabetic children) containing $12.3 \mathrm{KfU} / \mu \mathrm{lgG}$-(top panel) and $4.2 \mathrm{KfU} / \mu \mathrm{I}$ IgA-anti-BSA antibodies. C: Anti-BSA standard curves for enzyme immunoassay (EIA). KfU, Kilo fluorescence units. D: Binding competition with increasing amounts of free ovalbumin/Tween-20 for IgG$(-)$ and IgA- - anti-BSA antibodies, as well as with increasing amounts of free BSA for IgG$(\rightarrow)$ and IgA- $(-)$ anti-BSA antibodies jects and control subjects were more subtle than those observed in our study [6].

We modified an anti- $\beta$-lactoglobulin EIA procedure [18] for the measurement of BSA antibodies and compared it and the PCFIA procedure in their ability to detect diabetes-associated BSA antibodies. We found that each technique detected a different subset of anti-BSA antibodies. PCFIA measured highly disease-associated BSA antibodies, whereas EIA measured antibodies more common in the general population.

\section{Subjects and methods}

\section{Study population}

Forty Finnish diabetic children (22 males, mean \pm SD age $6.2 \pm 4.5$ years, range $0.9-15.5$ years) from our previous study [6] were randomly selected for assay comparison and contained a typical range of elevated levels of BSA antibodies (Fig. 1 A). Samples were drawn at the time of diagnosis of diabetes, and selected sera were sent coded back to the laboratory in Finland (E.S.) to be analysed by EIA. Control subjects comprised 179 age- and sexmatched non-diabetic Finnish children (98 males, mean \pm SD age $6.2 \pm 3.6$ years, range $0.9-15.9$ years) whose samples were shared between the laboratories. All samples were studied without knowledge of the sample origin.

\section{Particle concentration fluoroimmunoassay (PCFIA)}

PCFIA is a solid-phase immunoassay technique employing 96-well unidirectional flow vacuum filtration plates and a very high-surfacearea solid phase (carboxylated polystyrene microspheres) covalent- ly conjugated with the antigen [7]. Phase separation procedures are carried out by robotic Screen-Machine Instruments (IDEXX, Portland, Me., USA), which is progammable for reagent additions, timed incubations, phase separations, washings and measurements of particle-bound fluoresceinated secondary antibody $[10,19]$.

Two-hundred microlitres of BSA (Grade V; Sigma Chemical Co., St Louis, Mo., USA, 10\% in phosphate-buffered saline (PBS; $40 \mathrm{~g} \mathrm{NaCl}, 1 \mathrm{~g} \mathrm{KCl}, 1 \mathrm{~g} \mathrm{KH}{ }_{2} \mathrm{PO}_{4}, 5.75 \mathrm{~g} \mathrm{Na}_{2} \mathrm{HPO}_{4}, 0.5 \mathrm{~g} \mathrm{CaCl}_{2}, 0.5 \mathrm{~g}$ $\mathrm{MgCl}_{2} / 51$ distilled water, $\left.\mathrm{pH} 7.2\right)$ ) was coupled covalently ( $100 \mu \mathrm{l}$ of $10 \mathrm{mg} / \mathrm{ml}$ 1-ethyl-3-(3-dimethylaminopropyl)-carbodimide) onto $400 \mu \mathrm{l}$ ( $5 \%$ stock; IDEXX) carboxylated polystyrene beads (diameter $0.75 \mu \mathrm{m}$ ). Subsequently, $10 \%$ Tween-20 in $1.0 \%$ ovalbumin-PBS was used as blocking agent. After repeated washings, beads were stored in $1 \%$ Tween-20-PBS. Over a period of 9 months the activity of the beads remained unchanged.

Twenty microlitres of test serum dilutions $(1: 100-1: 1,000)$ were added to microwells containing $20 \mu \mathrm{l}$ of $1: 20$ diluted BSA-coated microspheres (initial $2.5 \%$ weight/volume). Up to ten plates were inserted into the Screen-Machine for programmed phase separations, washings and addition (100 ng/well) of affinity purified, custom BSA-free fluorescein-conjugated goat anti-human $\operatorname{IgG}, \operatorname{IgA}$, and $\operatorname{IgM}\left(\mathrm{F}_{\mathrm{c}}\right.$-fragment specific; BioCan, Mississauga, Ontario, Canada). Drying and precipitation of serum protein was avoided by short (1 min) incubation, phase separation and washing procedures at low ( $5 \mathrm{~mm} \mathrm{Hg}$ ) vacuum pressure. Prior to reading, wells were vacuum dried for $1 \mathrm{~min}$ and fluorescence emission was read under high vacuum from the concentrated particle cake at the bottom of the well. Kinetics of the system have been published [7]. We have processed up to 3,000 replicate samples per day per instrument per operator. The PCFIA assay had a sensitivity of less than or equal to $1 \mathrm{ng}$ antibody per $\mathrm{ml}$ and analysis of 400 consecutive assays delineated intraand inter-assay variations of $8.9 \%$ and $9.8 \%$, respectively.

An in-house (positive) standard serum pool from diabetic children was used and a standard curve prepared in every plate (Fig. 1B). Competition experiments showed satisfactory specificity for BSA. Free BSA blocked antibody binding in a dose-dependent 
Table 1. Frequency of elevated anti-bovine serum albumin antibodies in diabetic $(n=40)$ and control children $(n=179)$ as defined by particle concentration fluoroimmunoassay (PCFIA) and by enzyme immunoassay (EIA)

\begin{tabular}{lllllll}
\hline Isotype & \multicolumn{2}{l}{ Positive diabetic children $n(\%)$} & & \multicolumn{2}{l}{ Positive control children $n(\%)$} \\
\cline { 2 - 6 } & PCFIA & EIA & $p$ & & PCFIA & EIA \\
\hline $\operatorname{IgG}$ & $40^{\mathrm{a}}(100 \%)$ & $10^{\mathrm{b}}(25 \%)$ & $<0.0001$ & $4(2.2 \%)$ & $18(10 \%)$ & $<0.002$ \\
$\operatorname{IgA}$ & $20^{\mathrm{a}}(50 \%)$ & $17^{\mathrm{a}}(42 \%)$ & NS & $6(3.3 \%)$ & $18(10 \%)$ & $<0.01$ \\
\hline
\end{tabular}

${ }^{\mathrm{a}} p<0.0001,{ }^{\mathrm{b}} p<0.05$ for difference between antibody positive diabetic patients and control children using PCFIA and EIA

fashion, whereas neither ovalbumin nor Tween-20 nor a combination of the two were able to displace the antibody (Fig. 1D). Results are expressed as kilo fluorescence units (KfU) per microlitre based on instrument gain $(5 \times)$, serum dilution and assay volume as derived from the standard containing $12,300 \mathrm{KfU} / \mathrm{ml} \mathrm{IgG}-$ and $4,200 \mathrm{KfU} / \mathrm{ml} \mathrm{IgA}$-anti-BSA antibodies. Due to the linearity of fluorescence emission energy the values were normally distributed. Elevated antibody levels were defined to exceed the mean level in control subjects plus $2 \mathrm{SD}$.

\section{Enzyme linked immunosorbent assay (EIA)}

Our EIA for the measurement of anti-BSA is a conventional threelayer solid-phase procedure modified from Tainio et al. [18]. The method employs polystyrene Microstrip wells (Labsystems, Helsinki, Finland) that are processed in an automatic EIA analyser (AutoEIA II; Labsystems, Helsinki, Finland), which can process up to three plates (66 samples) per day. The plates were coated with $100 \mu \mathrm{l}(2 \mathrm{mg} / \mathrm{ml}) \mathrm{BSA}(\mathrm{A}-4378$; Sigma) in $0.1 \mathrm{~mol} / \mathrm{l}$ PBS-5 mmol/1 $\mathrm{NaN}_{3}$ (pH 7.4) overnight at room temperature. After washing with PBS-NaN ${ }_{3}$, the wells were saturated with $1 \%$ gelatin-PBS-NaN ${ }_{3}$ for 1 h at $37^{\circ} \mathrm{C}$ and stored at $+4^{\circ} \mathrm{C}$ until used.

Serum samples were diluted $1: 40$ in $0.5 \%$ gelatin-PBS-NaN $\mathrm{NaN}_{3}$ prepared in $0.05 \%$ Tween-20. Three replicates of $100 \mu \mathrm{l}$ of serum dilutions were plated, two in coated wells and one in a non-coated well. After a 60 -min incubation at $37^{\circ} \mathrm{C}$ wells were washed four times. Diluted alkaline phosphatase conjugated anti-human IgG or -IgA (cat. no.67806 and 67808; Orion Diagnostica, Espoo, Finland) was added and incubated for $60 \mathrm{~min}$ followed by four washes. After 45 -min incubation of substrate $(2 \mathrm{mg} / \mathrm{ml}$ p-nitrophenyl phosphate in $\mathrm{N}$-N-diethylaniline buffer) the reaction was stopped with $1 \mathrm{~mol} / \mathrm{l}$ $\mathrm{NaOH}$. Absorbances (optical density $405 \mathrm{~nm}$ ) in non-coated wells were subtracted from test values.

Intra-assay- and inter-assay variations were $9.3 \%$ and $15.8 \%$, respectively. For serum assays, serial dilutiona of a BSA-antibody positive standard were run on each plate (Fig. 1C) and the results expressed as percent binding of the standard serum. Values for both IgG- and IgA were skewed despite log-transformation, and thus the limit for positivity was set at the 90th percentile of the values in control subjects. This limit was selected after examining a series of cutoff values as giving the highest sensitivity with acceptable specificity. Sera having an absorbance of $3.9 \%$ for $\operatorname{IgG}$ and $14.2 \%$ for $\operatorname{IgA}$ of the standard were considered as positive.

\section{Statistical analysis}

Statistical analysis was performed using cross-tabulation, chi-square statistics and Student's unpaired $t$-test in the case of normally distributed variables. Since the distribution of BSA antibody levels obtained by EIA was skewed despite transformation, the difference between diabetic and control children was evaluated by a MannWhitney U-test. Mann-Whitney U-test and Spearman's rank-correlation test were used to compare antibody levels between EIA and PCFIA. Sensitivity and specificity of the assays was determined, and the results evaluated by cross-tabulation with chi-square statistics. Results are presented as means \pm SEM.

\section{Results}

The 40 sera from diabetic children contained a range of elevated IgG-anti-BSA ${ }^{\text {PCFIA }}$ antibodies; however, only $25 \%$ were found positive in EIA (Table $1, p<0.0001$ ). Conversely, IgG-anti-BSA ${ }^{\mathrm{EIA}}$ antibodies in control subjects were elevated more frequently than those detected by PCFIA (Table $1, p<0.002$ ). Elevated IgA-anti-BSA antibodies in diabetic children were found in $50 \%$ and $42 \%(p=\mathrm{NS})$, however only $3.3 \%$ and $10 \%$ of control children were positive in PCFIA and EIA, respectively (Table $1, p<0.01$ ). These results demonstrated that PCFIA but not EIA preferentially detects disease-associated BSA antibodies in children with Type 1 diabetes. In contrast, EIA shows preference for detection of antibodies more prevalent in the general population. Neither procedure detected all BSA antibodies.

BSA antibody levels in diabetic children are shown in Figure 2. There was a significant difference in the levels of both IgG-, and IgA-anti-BSA antibodies between diabetic and control children when determined by PCFIA $(p<0.001$ and $p<0.001)$. In contrast, the levels of IgGanti-BSA ${ }^{\mathrm{EIA}}$ antibodies were roughly similar in diabetic and control children. IgA-anti-BSA ${ }^{\text {EIA }}$ antibodies were higher in diabetic children, but the difference $(p<0.01)$ was less prominent than in PCFIA $(p<0.001)$. These findings suggest a quantitative difference in the subsets of antibodies detected by PCFIA, and this difference distinguishes diabetic and control children.

Individual PCFIA- and EIA values are compared in Figure 3 for diabetic and control children. Shaded areas indicate the levels considered as negative (see Methods). The correlation between PCFIA and EIA was very poor $\left(-0.05 \leq r_{\mathrm{s}} \leq 0.28,0.09 \leq p \leq 0.1\right)$. In diabetic subjects only a subset of sera. (IgG: $\sim 20 \%$ and IgA: $\sim 32 \%$ ) gave relatively low or high anti-BSA values in both assays i.e. showed correlation. Moreover, among. control subjects only one IgA sample $(0.3 \%)$ was positive in both assays.

BSA-antibodies in control sera bound significantly more frequently in EIA than in PCFIA (IgG: $p<0.002$ and IgA: $p<0.01$, Table 1) and only one out of the 18 control subjects positive for IgG- or IgA-anti-BSA ${ }^{\mathrm{EIA}}$ was positive by PCFIA. On the other hand, of the four IgG- and six IgA-positive control sera detected by PCFIA, only one was positive by EIA (Fig. 3). Therefore, most disease-associated BSA-antibodies were only detected by PCFIA. The sensitivity of PCFIA in detecting disease-associated IgG anti-BSA antibodies was excellent when compared to EIA (100\% vs $25 \%$, 

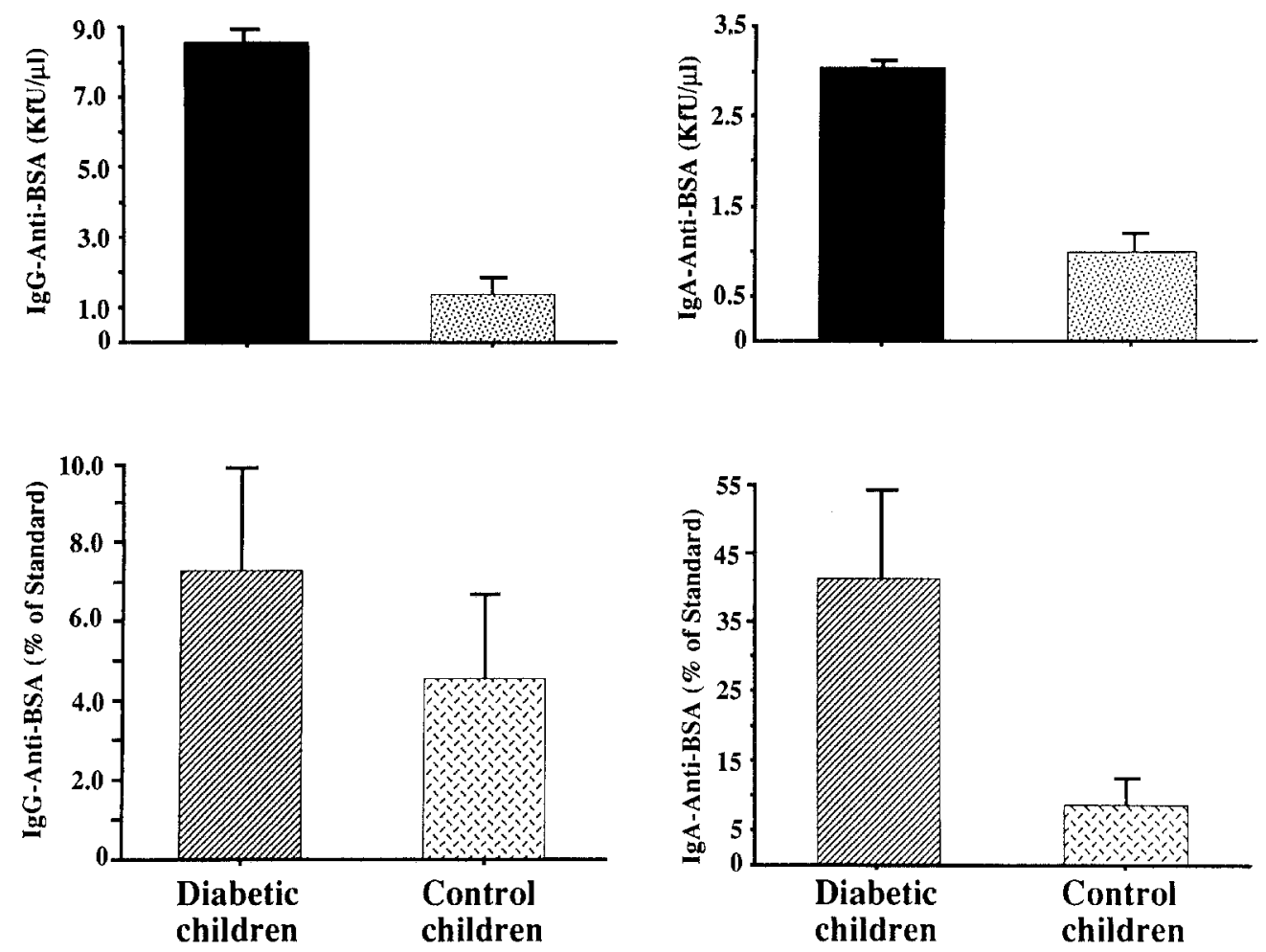

Fig. 2. Mean levels ( \pm SEM) of anti-bovine serum albumin (BSA) antibodies in Type 1 (insulin-dependent) diabetic- and matched control children as detected by particle concentration fluoroimmunoassay (PCFIA, upper panels) and enzyme immunoassay (EIA, lower panels). Difference between diabetic and control children: PCFIA: IgG, $p<0.0001 ; \operatorname{Ig} \mathrm{A}, p<0.001$. EIA: $\operatorname{IgG}, \mathrm{NS} ; \operatorname{IgA}, p<0.01$

A

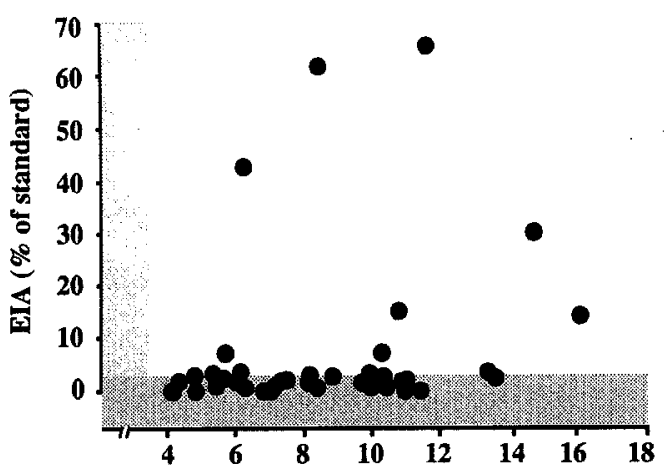

B

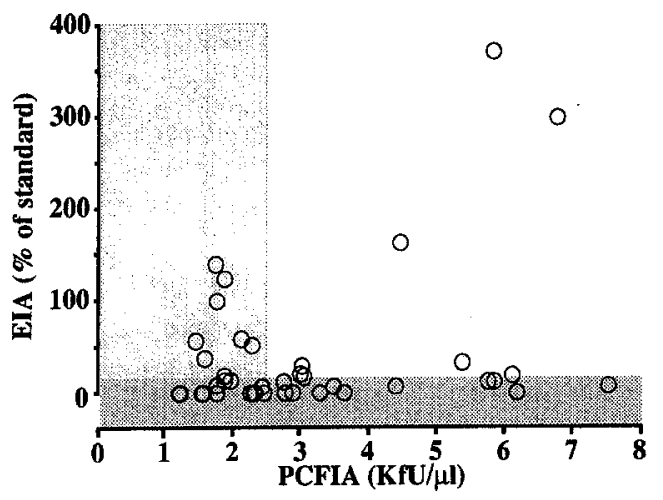

C
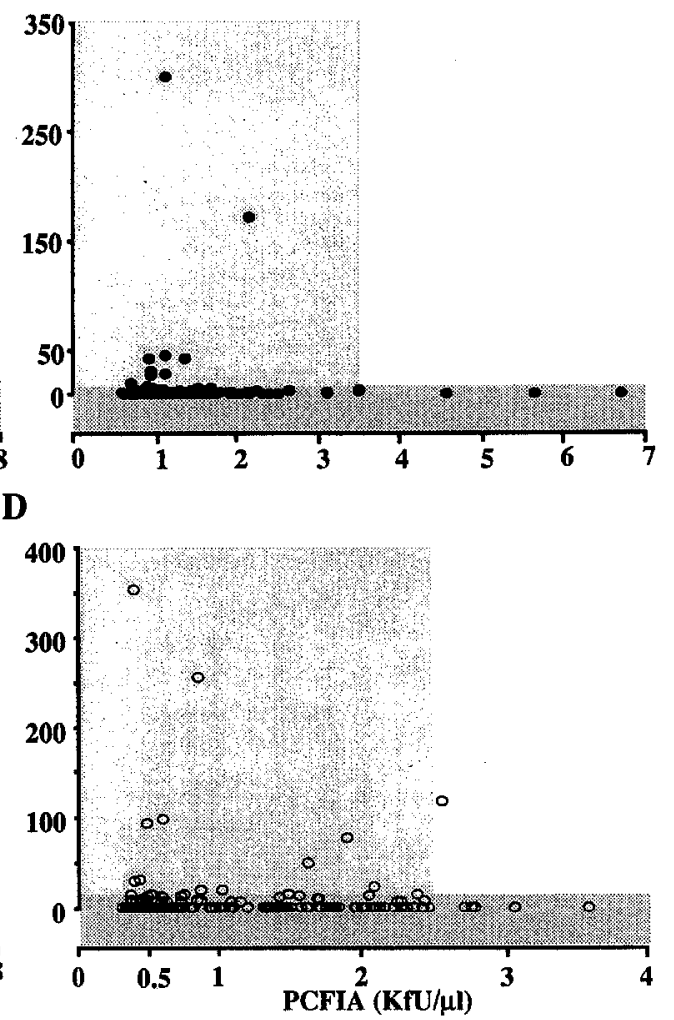

Fig. 3A-D. Correlation between the levels of anti-bovine serum albumin (BSA) antibodies as determined by enzyme immunoassay (EIA) and particle concentration fluoroimmunoassay (PCFIA) in diabetic-and control children. Shaded areas represent BSA-antibody levels considered as "nonelevated" (T) negative for BSA antibodies by PCFIA, negative for BSA antibodies by EIA). A: $\operatorname{IgG}$ in diabetic children, $n=40, r_{\mathrm{s}}=0.28, p=0.09$; B: IgA in diabetic children, $n=40, r_{\mathrm{s}}=0.11, p=0.48$ C: $\mathrm{IgG}$ in control children, $n=179, r_{\mathrm{s}}=0.02, p=1.0$; D: $\operatorname{Ig} \mathrm{A}$ in control children, $n=179, r_{\mathrm{s}}=-0.05, p=1.0$. Correlation coefficients were determined by Spearman's rank correlation
Table 2; $<<0.0001)$ and the disease-specificity was higher for PCFIA (Table 2; $p<0.02$ ). For the IgA isotype assay results were comparable with respect to disease-sensitivity, but in EIA this was at the cost of disease specificity $(p<0.05)$. These findings suggest that PCFIA and
EIA preferentially detect different subsets of BSA antibodies with no (IgG) or some overlap (IgA). Antibodies detected in EIA are poorly associated with Type 1 diabetes and are found commonly in the general population. 
Table 2. Sensitivity and specificity of particle concentration fluoroimmunoassay (PCFIA) and enzyme immunoassay (EIA) in detecting anti-bovine serum albumin antibodies

\begin{tabular}{lcllllll}
\hline & \multicolumn{2}{c}{ Sensitivity (\%) } & & \multicolumn{3}{c}{ Specificity (\%) } \\
\cline { 2 - 3 } & PCFIA & EIA & $p$ & PCFIA & EIA & $p$ \\
\hline IgG & 100 & 25 & $<0.0001$ & 98 & 90 & $<0.02$ \\
$\operatorname{IgA}$ & 50 & 42 & NS & 97 & 90 & $<0.05$ \\
\hline
\end{tabular}

\section{Discussion}

Epidemiological evidence in man $[4,20-22]$ and data from animal feeding studies $[13,23-25]$ have suggested a diabetogenic effect of dietary cow's milk proteins. Supportive serological findings have been identified in animals [12, 13] and humans [15-17] associating immunity to cow's milk proteins with Type 1 diabetes. The most direct evidence for a pathogenic link between cow's milk proteins and diabetes comes from a family study in Finland, where exclusive breast-feeding for the first 3-4 months of life was found to protect from later development of diabetes [22].

Most of these studies did not identify a specific cow's milk protein or explain the near global increase in diabetes incidence despite emphasis on breast-feeding. However, these latter observations [22] are consistent with the view that in humans (as in diabetes-prone rats [13]) a diabetes associated immune response to BSA/ ABBOS is triggered in the early post-natal period $[1,26]$. The link of BSA/ABBOS to human diabetes was made by finding elevated antibody levels against BSA in all newly-diagnosed patients, the bulk of this response specific for the ABBOS epitope [6].

In order to compare the PCFIA assay procedure to the more commonly available EIA, we analysed a large number of samples using both techniques. The comparison revealed unequivocal differences: with diabetes-associated anti-BSA molecules detected almost exclusively by PCFIA. Both, levels and frequency of positive responses among diabetic children were significantly higher in PCFIA than EIA. The wide scatter of antibody levels in EIA for both patients or control subjects caused major overlap between the groups and made differences statistically insignificant. A large proportion of samples were below the detection limit of EIA, causing considerable skewness for measurement of both isotypes examined.

PCFIA detected BSA antibodies in children with diabetes, whereas only a few non-diabetic children were positive. In contrast, only a small proportion of the antibodies were disease-associated in EIA, and levels were elevated more often in non-diabetic subjects. With only one out of the 18 controls positive for IgG or IgA-anti$\mathrm{BSA}^{\mathrm{EIA}}$ elevated by PCFIA as well, the dichotomy was clear between antibody subsets detected in either procedure. Interestingly, the single elevated $\operatorname{IgG}$ and $\operatorname{IgA}$ values detected in both procedures derived from the same serum sample, suggesting that the host determines the choice of antibody species utilized in the common immune response to dietary BSA.
The BSA molecule consists of 608 amino acids and there are several areas where the sequence differs from human serum albumin. One of those is the described ABBOS peptide (pre-BSA position 153-169 [2]). As we have recently shown [6], most of the diabetes-associated antibodies detected by PCFIA in diabetic children are directed against this epitope, whereas in non-diabetic control subjects the major epitopes are different, with less than $3 \%$ of donors able to recognize ABBOS [6]. Since the $\mathrm{ABBOS}$ epitope is immunologically cross-reactive with a (Beta-cell) autoantigen, p69 $[1,3]$, the poor immunogenicity of this epitope in the general population is not surprising and clearly identifies the diabetic population. We have tentatively linked this principal difference to efficient antigen presentation of $\mathrm{ABBOS}$ by diabetes-associated MHC class II molecules coupled with a delay in oral (or mucosal) tolerance development in diabetic subjects $[1,3]$ : our focus on the latter was triggered by the report that the single highest marker of diabetes risk (DQ $\beta$ non-ASP ${ }^{57}$ ) also marks susceptibility for IgA deficiency, a regulatory abnormality of mucosal immunity $[27,28]$.

An antigen such as BSA has several epitopes which can induce a wide spectrum of high and low affinity antibodies. Our results are very reminiscent of the observation that insulin-autoantibodies (IAA) detected by EIA are poorly disease-associated [29] and have a low predictive value compared to fluid-phase radiobinding assays (RIA) [30-32]. EIA has been characterized by low sensitivity and an unacceptably high rate of false positives [29], similar to the results obtained in this study. EIA detects mainly low affinity IAA that have high binding capacity, whereas RIA detects high affinity, low binding capacity and strongly disease-associated subset(s) of IAA [32]. The same could apply to a fluid-phase assay such as PCFIA, in which accessibility to the epitopes may be different from EIA. The same epitopes may not be available PCFIA and EIA due to different binding procedures. Disease-associated epitopes may not be accessible if bound to EIA plate [33]. On the other hand, an excess of adhesive antigens on EIA-plate surface may bias binding of non-disease-associated, low affinity antibodies with high binding capacity as reported for IAA in healthy blood donors [34].

The striking lack of correlation between the two assay systems is less suggestive of gradual differences in average antibody affinity, but indicates absolute distinctions in the quality of antibodies detected. Maturation of an antigen driven (hyper-) immune response produces an antibody repertoire that is not only of high affinity but also favours immunoglobulins with fast binding kinetics [35], i.e. antibodies characterized by high on-off antigen binding rates and release required, for example, for rapid opsonization of pathogens and re-utilization of antibody. We speculate that the combination of large-surface area of antigen-conjugated microspheres, consequent ease of antigen accessibility and the fast dynamics of PCFIA ( 1 min binding periods) all contribute to the preferential detection of antibodies with a high on-off binding rate. If correct, then the presence of such antibodies supports our claim that these diabetes-associated antibodies are the product of a stringently antigen-driven immune response [6]. In any case, the observations presented here emphasize the im- 
portance of clinical validation for serological assay procedures which rarely cover all possible immunoglobulin repertoires able to associate with a given antigen.

Acknowledgements. This work was supported by the Medical $\mathrm{Re}$ search Council of Canada, the Research and Science Foundation of Farmos, Turku, and the Foundation for Paediatric Research, Helsinki, Finland. J. K. is a postdoctoral fellow of the Sigrid Juselius Foundation, Helsinki, Finland.

\section{References}

1. Dosch H-M, Karjalainen J, Morkowski J, Martin JM, Robinson BH (1992) Nutritional triggers of IDDM. In: Levy-Marchal C, Czernichow P (eds) Pediatric and adolescent endocrinology. Karger, Basel, pp 202-217

2. Glerum M, Robinson BH, Martin JM (1989) Could bovine serum albumin be the initiating antigen ultimately responsible for the development of insulin dependent diabetes mellitus? Diabetes Res 10: 103-107

3. Martin JM, Trink B, Daneman D, Dosch H-M, Robinson BH (1991) Milk proteins in the etiology of insulin-dependent diabetes mellitus (IDDM). Ann Med 23: 447-452

4. Elliott RB, Reddy SN, Bibby NJ, Kida K (1988) Dietary prevention of diabetes in the non-obese diabetic mouse. Diabetologia 36: $62-64$

5. Scott FW, Daneman D, Martin JM (1988) Evidence for a critical role of diet in the development of insulin-dependent diabetes mellitus. Diabetes Res 7: 153-157

6. Karjalainen J, Martin JM, Knip M et al. (1992) Evidence for a bovine albumin peptide as a candidate trigger of Type 1 diabetes. $\mathrm{N}$ Engl J Med 327: 302-307

7. Dosch HM, Lam P, Guerin D, Leeder JS (1988) Characteristics of particle concentration fluorescence immunoassay (PCFIA): novel alternatives to ELISA and RIA, In: Gembala P-L (ed) Proceedings of the 1987 Pandex Symposium on particle concentration fluorescence immunoassay, Baxter Healthcare Corporation, Chicago, pp 5-22

8. Hui MF, Lam P, Dosch HM (1989) Properties and heterogeneity of human fetal pre-B cells transformed by EBV. J Immunol 143: 2470-2479

9. Dosch HM, Lam P, Hui MF, Hibi T (1989) Concerted generation of Ig isotype diversity in human fetal bone marrow. J Immunol 143:2464-2469

10. Dosch H-M, Lam P, Hui MF, Hibi T, Cheung RK (1990) EBV utilizes a unique activation pathway for the transformation of human B cells. Int Immunol 2: 833-848

11. Walter MH, Dosch H-M, Cox DW (1991) A deletion map of the human immunoglobulin heavy chain region. J Exp Med 174: 335 349

12. Beppu H, Winter WE, Atkinson MA, Maclaren NK, Fujita K, Takahashi H (1987) Bovine albumin antibodies in NOD mice. Diabetes Res 6: 67-69

13. Scott FW, Cloutier HE, Souligny J, Riley WJ, Hoorfar J, Brogren $\mathrm{CH}$ (1989) Diet and antibody production in the diabetes-prone $\mathrm{BB}$ rat. In: Larkins $\mathrm{R}$, Zimmet $\mathrm{P}$, Chisholm D (eds) Diabetes 1988. Proceedings of the 13 th International Diabetes Federation. congress. Elsevier Science, Amsterdam, pp 763-767

14. Colman PG, Campbell IL, Kay TWH, Harrison LC (1987) $64000-\mathrm{M}_{\mathrm{r}}$ auto-antigen in type 1 diabetes: evidence of its location on human islets. Diabetes 36: 1432-1440

15. Yokota A, Yamaguchi Y, Ueda Y et al. (1990) Comparison of islet cell antibodies, islet cell surface antibodies and anti-bovine serum albumin antibodies in type 1 diabetes. Diabetes Res Clin Prac 9: 211-217

16. Savilahti E, Åkerblom HK, Tainio V-M, Koskimies S (1988) Children with newly diagnosed insulin dependent diabetes mellitus have increased levels of cow's milk antibodies. Diabetes Res 7: $137-140$

17. Pocecco M, Nicoloso F, Tonini G, Presani G, Marinoni S (1991) Increased levels of cow's milk antibodies in children with newly diagnosed insulin-dependent diabetes mellitus (IDDM). Horm Res 35: 67

18. Tainio VM, Savilahti E, Arjomaa P, Salmenperä L, Perheentupa J, Siimes M (1988) Plasma antibodies to cow's milk are increased by early weaning and consumption of unmodified milk, but production of plasma IgA and IgM cow's milk antibodies is stimulated even during exclusive breast-feeding. Acta Paediatr Scand 77: $807-811$

19. Cheung RK, Dosch H-M (1991) The tyrosine kinase lck is critically involved in the growth transformation of human B lymphocytes. J Biol Chem 266: 8667-8670

20. Borch-Johnsen K, Joner G, Mandrup-Poulsen T et al. (1984) Relation between breast-feeding and incidence rates of insulin-dependent diabetes mellitus. Lancet II: 353-360

21. Scott FW (1990) Cow milk and insulin-dependent diabetes mellitus: is there a relationship? Am J Clin Nutr 51: 489-491

22. Virtanen SM, Räsänen L, Aro A et al. (1991) Infant feeding in Finnish children less than $7 \mathrm{yr}$ of age with newly diagnosed IDDM. Childhood Diabetes in Finland Study Group. Diabetes Care 14: 415-417

23. Elliott RB, Martin JM (1984) Dietary protein: a trigger of insulin-dependent diabetes in the BB rat? Diabetologia 26: 297299

24. Daneman D, Fishman L, Clarson C, Martin JM (1987) Dietary triggers of insulin-dependent diabetes in the $\mathrm{BB}$ rat. Diabetes Res 5: 93-97

25. Scott FW, Marliss EB (1991) Conference summary: diet as an environmental factor in development of insulin-dependent diabetes mellitus. Can J Physiol Pharmacol 69: 311-319

26. Pilcher CC, Dickens K, Elliott RB (1991) ICA only develop in early childhood. Diabetes Res Clin Pract 14 [Suppl 1]: S82 (Abstract)

27. Dosch H-M, Hui MF, Doherty PJ (1992) Development of normal and abnormal immune function in man. Dev Immunol 2 (in press)

28. Olerup O, Smith CIE, Hamarström L (1990) Different amino acids at position 57 of the HLA-DQ beta chain associated with susceptibility and resistance to IgA deficiency. Nature 347:289290

29. Caudwell J, Stojanovski C, Colma P (1991) Caution against the use of commercial ELISA kit assays for preclinical IDDM screening. Diabetes Res Clin Pract 14 [Suppl 1]: S89 (Abstract)

30. Kuglin B, Kolb H, Greenbaum C, Maclaren NK, Lernmark A, Palmer JP (1990) The fourth international workshop on the standardisation of insulin autoantibody measurement. Diabetologia 33: 638-639

31. Levy-Marchal C, Bridel MP, Sodoyez-Goffaux F et al. (1991) Superiority of radiobinding assay over ELISA for detection of IAAs in newly diagnosed type 1 diabetic children. Diabetes Care 14: 61-63

32. Greenbaum GJ, Palmer JP, Kuglin B, Kolb H (1992) Insulin autoantibodies measured by RIA methodology are more related to IDDM than those measured by ELISA. J Clin Endocrinol Metab 74: 1040-1044

33. Sodoyez-Goffaux F, Koch M, Dozio N, Brandenburg D, Sodoyez J-C (1988) Advantages and pitfalls of radioimmune and enzyme linked immunosorbent assays of insulin antibodies. Diabetologia 31: 694-702

34. Sodoyez J-C, Sodoyez-Goffaux F, Koch M, Bouillenne C, Francois-Gerard C, Bosi E (1990) Clonally restricted insulin autoantibodies in a cohort of 2200 healthy blood donors. Diabetologia 33: $719-725$

35. Foote J, Milstein C (1991) Kinetic maturation of an immune response. Nature 352: 530-532

Received: 24 March 1992

and in revised form: 12 June 1992

Dr. H.-M. Dosch, Division of Immunology and Cancer

The Hospital for Sick Children, 555 University Avenue

Toronto, Ontario M5G 1 X8

Canada 